\title{
Chinese Investment in Turkey: The Belt and Road Initiative, Rising Expectations and Ground Realities
}

\author{
BURAK GÜREL*\& MINAKOZLUCA** \\ *Department of Sociology \& Center for Asian Studies, Koç University, Istanbul, \\ Turkey. Email: bgurel@ku.edu.tr \\ **Department of International Development, London School of Economics and \\ Political Science, London, UK. Email: m.kozluca@1se.ac.uk
}

\begin{abstract}
Turkey's inclusion in the Belt and Road Initiative in 2015 has raised the expectations of Turkish businesses and government concerning growth-generating investment from China. Existing studies on Chinese investments in Turkey lack sufficient data on the volume of investment, types of firms, and sectoral composition. Based on a novel dataset of Chinese investments in Turkey, this article contributes to filling this gap. We show that although Chinese investment in Turkey has increased considerably in recent years, it remains quite modest compared with investments from the West. Moreover, despite the expanding activities of Chinese technology companies, more than half of Chinese investment in Turkey consists of low value-added manufacturing, extraction of raw materials, and marketing of Chinese products. Overall, the developmental potential of Chinese investment in Turkey has not been radically different from other countries' investments.
\end{abstract}

\section{Introduction}

According to the World Bank's World Development Indicators, the ratio of net outflows of foreign direct investment (FDI) to the world average of gross domestic product (GDP) has increased six-fold over the last four decades (World Bank n.d.). This demonstrates the growing significance of overseas foreign direct investment (OFDI) as a facilitator of economic development in advanced and developing economies alike (Wu et al. 2020, 2). The emergence of China as a key actor in the global economy has been accompanied by the unprecedented increase in its overseas investments. Chinese OFDI increased from \$28 billion in 2000 to almost \$120 billion in 2019 (Ramasamy and Yeung 2020). As of 2019, China is the fourth largest source 
of capital in the world in terms of its FDI outflows (UNCTAD, 2020), pointing to its increasing importance for its economic development, as well as that of recipient countries (Abeliansky and Martínez-Zarzoso 2019, 2).

In discussing the trajectory of contemporary Chinese investment in foreign economies, one crucial dynamic to address is the Belt and Road Initiative (BRI). Formally initiated by president Xi Jinping in 2013, the BRI aimed to encourage interconnectivity and regional cooperation across Asia, Europe and Africa through infrastructure construction and multilateral and bilateral cooperation mechanisms (Deng et al. 2020). Covering 140 countries and six development corridors worldwide (Nedopil 2021), the potential consequences of the BRI have been a terrain of intense debate. Much of the literature on the BRI has emphasized its role as a diplomatic tool and presented it as a corollary of China's aspirations to expand its global influence and its ability to exert power over and extract resources from different territories (Flint and Zhu 2019; Jakimów 2019; Katsumata and Nagata 2019; Kim 2019; Rana 2019; Sneddon 2015; Sparks 2018). The recent literature has increasingly discussed the political economy of the BRI in terms of (i) Chinese OFDI (Liu et al. 2018; Ramasamy and Yeung 2020; Shao 2020; Zheng and van Vliet 2018); (ii) the sustainability of affiliated investments (Bandiera and Tsiropoulos 2020; Carmody 2020); (iii) its ability to bring about developmental gains in recipient countries (Chen 2021; Fon et al. 2021); and (iv) its environmental effects (Chernysheva et al. 2019; Liu et al. 2020; Nedopil 2021). While China-led infrastructure construction within the global South is viewed as an opportunity for industrial development by some (Arrfat 2020, 204), others have critiqued the BRI for failing to bring about 'local capacity building and knowledge transfer' (Khalili 2021). Despite ongoing contestations and immense regional variation of the project outcomes, the BRI is nevertheless said to be promoting a 'new global political economy' that facilitates the circulation of Chinese FDI based on 'South-South economic integration' (Camba and Hung 2018, 298).

Using original data as well as available primary data and secondary sources, this article analyses the trajectory of Chinese capital in Turkey over the last decade. Turkey officially became a BRI member country in 2015 (Parlar Dal 2017). Between 2013 and 2020, Turkey received $1.31 \%$ of total Chinese investments. ${ }^{1}$ To date, merely $0.8 \%$ of BRI-affiliated projects have Turkish involvement. ${ }^{2}$ Based on ongoing and planned project cooperation, Turkey ranks as the 23rd highest recipient of Chinese investment out of the 80 countries included in the AEI data (Figure 1) and 37 th out of 148 countries in terms of project involvement (Refinitiv n.d.). ${ }^{3,4}$ Despite its modest ranking among other BRI member-countries, emergent scholarship from Turkey has paid increasing attention to the potentialities of this cooperation,

1. Authors' calculation based on AEI (2020).

2. Authors' calculation based on Refinitiv (n.d.).

3. Authors' calculation based on Refinitiv (n.d.) and AEI (2020).

4. Currently, there are 140 official BRI member-states. However, given the limitations of available data and non-member involvement in BRI related projects, the AEI (2020) and Refinitiv (n.d.) datasets record 80 and 148 countries, respectively. 


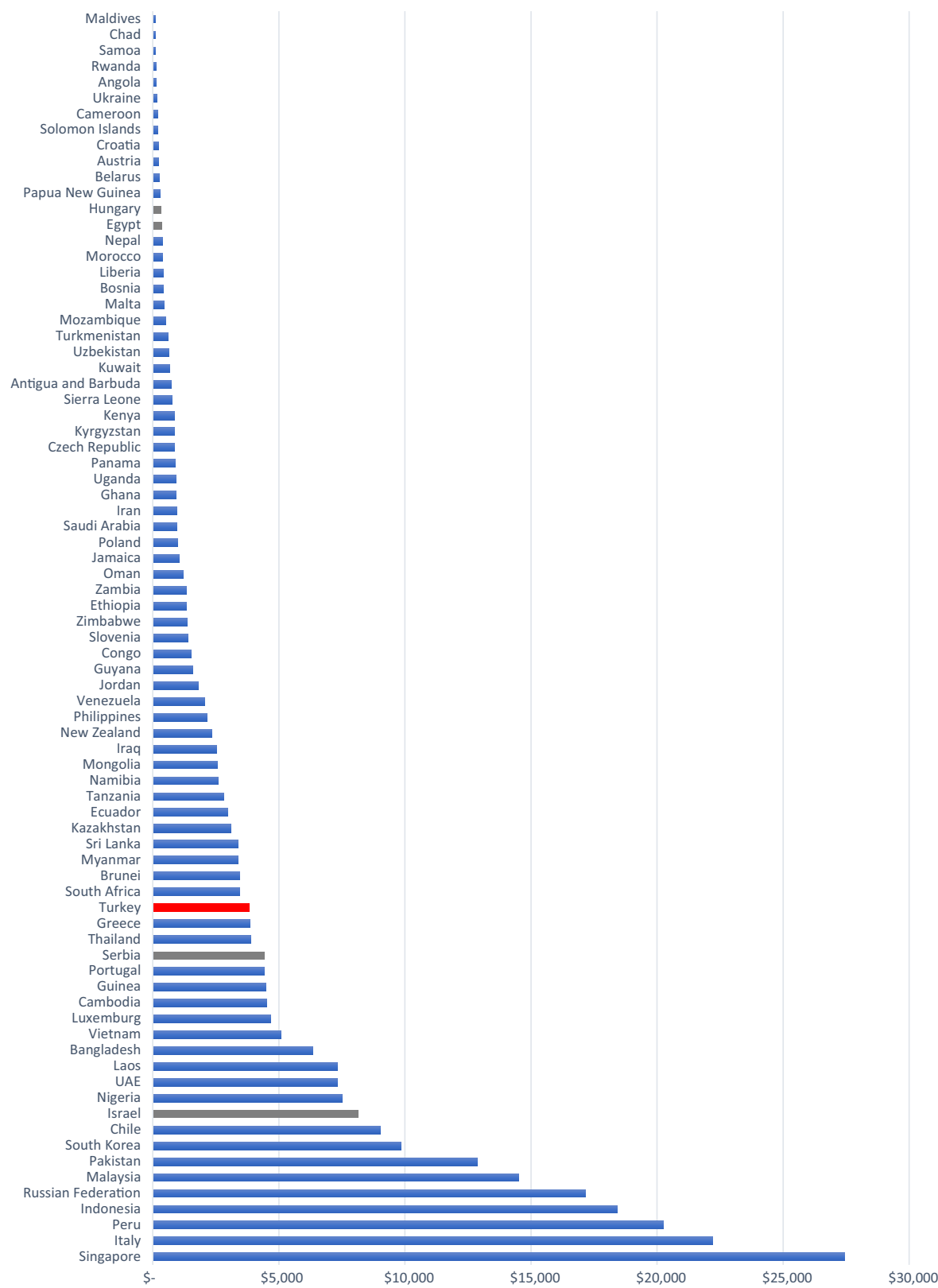

Figure 1. Country distribution of total Chinese investments over $\$ 100$ million (2013-2020)

Source: Authors' own calculations based on AEI (2020)

primarily revolving around the role of Chinese investment in the Turkish energy sector, multilateral transportation projects (Guo et al. 2019; Yildiran 2019), and Turkey's geostrategic position and the future of diplomatic relations with China (Akdağ 2019; Gaspers and Huotari 2017; Karaca 2019). While attempts at analysing 
the full extent of contemporary Chinese investment in Turkey are emerging (Atl 2019b; Ikiz 2019; Tekdal 2019), we argue that these studies are inevitably constrained by insufficient data. On the one hand, specific BRI projects and/or investments gain frequent and widespread coverage within Turkish and international news outlets; on the other hand, however, reliable data on the overall trajectory of Chinese investments are very limited. While the existence of bilateral and multilateral projects is important in and of itself, the lack of data to substantiate their position within the broader context of Chinese capital in Turkey can result in (a) exaggerating the extent of Chinese investment in Turkey, (b) an overemphasis of certain sectors at the expense of others, or (c) the sole reliance on provisional/simplistic accounts of Chinese OFDI.

A country's involvement with the BRI has far-reaching implications beyond project-based outcomes. Such implications include the availability of credit from development banks, increased economic engagement with Chinese state-owned enterprises (SOE) and private firms, and the generation of foreign interest in key domestic sectors (Du and Zhang 2018). Turkish government officials have explicitly declared their desire for the BRI to facilitate complementary trade relations between the two countries (Dünya Gazetesi 2014; 2020c). ${ }^{5}$ The trade volume between China and Turkey was over $\$ 22$ billion in 2019, with a \$20 billion trade deficit on the Turkish side - making China the biggest contributor to Turkey's current account deficit. In other words, while Turkey closing its trade deficit with China is an unlikely prospect in the short-run (Atl1 2019a, 81), Chinese investment is nevertheless viewed as having the potential to contribute to its economic development (Çolakoğlu 2021).

We argue that a thorough analysis of the two countries' economic relations is important in assessing the effects of Chinese investment in Turkey and drawing realistic conclusions about its potentialities for Turkey's developmental trajectory. Moreover, situating the Sino-Turkish economic integration in a comparative perspective with countries from the Middle East and North Africa (MENA) and Central and Eastern Europe (CEE) regions could unveil China's approach to different subregions of the BRI. Given the novelty of the BRI, it is best understood as a multifaceted and dynamic endeavour whereby the motivations, emphases and outcomes (both real and expected) are constantly negotiated by actors at different levels and across different sectors. Thus, it is crucial to avoid overemphasizing a specific project or sector from the arsenal of the initiative and attempting to draw macrolevel conclusions therein. The wealth of public discourse on the indispensability of China as an economic partner to Turkey could result in the potential exaggeration of its actual contribution to important developmental indicators such as the transfer of technical know-how, industrial upgrading, and capacity building. Despite an increase over the last decade, the volume of Chinese investment in Turkey is still insignificant (Atl1 2019b, 160). There are currently 1148 Chinese-invested firms operating in Turkey, with a total investment of just over $\$ 1$ billion. To put this number in

5. It should be noted that these overt calls for intensified cooperation occur despite widespread public criticism in Turkey regarding the treatment of Uyghurs in China's Xinjiang Autonomous Region (Ergenç 2015, 296-297). 
context, Norway has 277 firms operating in Turkey, with a total investment of $\$ 966$ million (TCSTB 2021). Moreover, China has only recently joined the group of middle-income countries. China's GDP per capita (in current \$) surpassed Turkey's in 2018 but is currently one-sixth of the US's GDP. Hence, dealing with domestic developmental bottlenecks will remain a policy priority for China. Domestic problems may lead to considerable fluctuations in foreign investment and aid (Chen 2018). Chinese capital in Turkey does not harbour explicitly developmental motives. While this does not rule out its ability to bring about potential benefits, it does warrant caution in the analyses of investments (Tekdal 2019, 127). Finally, the divisive political implications of increased Chinese presence within the developing world could also result in the mischaracterization or exaggeration of information by important outlets (Hung 2018, 3). Thus, scrutinizing the available data is extremely important.

Drawing on existing and novel data, this article critically assesses the trajectory of Chinese investment in Turkey. Based on a political economy perspective, we analyse the sectoral distribution and developmental capacity of Chinese capital currently operating in Turkey. Aside from painting a realistic picture of China's role in Turkey's economic development, our study also points to proper methodologies that might be used to follow the future of China's economic relations with different countries and regions.

The second section of this article reviews the existing scholarship examining the trajectory and motivations beneath contemporary Chinese OFDI and the political economy of Chinese capital for different countries and regions. The third section surveys the existing literature on Sino-Turkish relations and provides a critical overview of the available data on the subject. The fourth section presents our compiled novel dataset on Chinese investment in Turkey and our findings based on this dataset. The fifth section analyses our findings from a comparative perspective.

\section{Chinese Overseas Direct Investment under the BRI}

Although the BRI has recently emerged as an ambitious effort to increase China's geographical reach, China has demonstrated its potential to sustain considerable capital outflow for investment since the late 1990s (Wong and Chan 2003, 275). Thus, the BRI's role in facilitating economic cooperation should be placed in historical context. Due to the success of its export-oriented manufacturing, China has maintained a large trade surplus and foreign currency reserves since the 1990s. However, China has faced significant challenges in sustaining high economic growth due to increasing labour and input costs (Chen 2018, 42). Moreover, the Chinese economy's overcapacity problem and the increasing 'reindustrialization' trend within the Global North after the 2007-2008 global economic crisis have compelled Chinese capital to invest in new markets (Wang 2018, 273). The branching out of the Chinese economy in the last decade occurred through two mechanisms: the rise in Chinese OFDI by over $\$ 90$ billion in the last two decades (Zheng and van Vliet 
2018) and the unprecedented rise in Chinese foreign aid to other developing countries. According to China's Ministry of Finance, the total expenditure on foreign aid rose from $\$ 631$ million in 2003 to $\$ 2.3$ billion in 2016 (Hung 2018, 2).

The BRI is a culmination of this 'going out' strategy (Huang 2016, 314-315). The initiative aims to improve connectivity across a large landscape and facilitate investments in developing 'hard infrastructure, soft infrastructure, and cultural ties' among member countries. A total of 140 countries have already joined the BRI thus far (Nedopil 2021). As of October 2019, the participating countries cover $61 \%$ of the world's population and have a total GDP of \$29 trillion (ChinaPower 2021). The ambitious nature of the project and long-term projections for its implementation have resulted in its being labelled as a 'new great game' or the associated emergence of a 'Beijing consensus' within the global political sphere (Chen and Fazilov 2018; Hussain and Jamali 2019). These accounts conceptualize the BRI as an all-encompassing diplomatic endeavour aiming to exert Chinese influence over developing economies and prepare sufficient grounds to exploit key geographies (particularly in Africa) for their natural resources and cheap labour power without bringing about meaningful development (Hillman 2020). This view argues that the BRI is a type of 'debt-trap diplomacy' whereby China offers credit and loans with high-interest rates to politically and economically unstable countries. Coined by a think tank in northern India, the expression gained currency within academic studies and popular discourse to caution developing economies about the predatory nature of Chinese investment (Brautigam 2020). As the explanation goes, China deliberately imposes harsh terms in BRI investments, enabling the seizure of strategic assets if the recipient country experiences financial problems (Caixin Global 2018; Carmody 2020; Chellaney 2017; Sanderson and Forsythe 2012). However, studies on loan agreements and implementations have seriously challenged this understanding (Jones and Hameiri 2020; Singh 2020). A 2021 study analysing 100 debt contracts signed by China with foreign governments demonstrates that while these agreements do contain elements ensuring strict debt repayment mechanisms, the specified conditions differ 'in degree [and] not in kind' of conditions placed by commercial lenders (Gelpern et al. 2021). The enforcement of agreements is also subject to immense regional variability. An analysis of Chinese investment in railway construction in Ethiopia notes that due to their 'financial flexibility in the post-construction phase', local actors view Chinese loans more positively compared with private-sector commercial loans (Chen 2021, 13). Moreover, the characterization of all Chinese lending as predatory invites the risk of ignoring the agency of recipient countries. Jones and Hameiri $(2020,2)$ demonstrate that in Sri Lanka and Malaysia, loans were initiated by domestic governments, and debt problems were primarily due to the 'misconduct of local elites and Western-dominated financial markets'. Thus, the debt-trap diplomacy approach fails to grasp the diverse agencies of actors within recipient countries and Chinese capital, the range of projects and agreements that have been undertaken, and the regional variability of implementation and outcomes. 


\section{Determinants and Outcomes of Chinese Investment under the BRI}

Recent scholarship has begun to emphasize the necessity of addressing domestic economic concerns within China more vigorously when assessing the nature of contemporary Chinese OFDI. It has been demonstrated that the individual components of the BRI do not necessarily serve the same purpose on every occasion, and resource or asset extraction is rarely a feasible or viable endgame for China (Brautigam 2020). Situating the BRI into the larger process of liberalization of the Chinese economy after the reform and opening up in 1978, Jones and Zeng (2019) argue that as opposed to being a 'grand strategy', the BRI functions more as a collection of 'loose policy envelopes'. In other words, the planning, implementation, and outcomes of BRI projects are dependent on contestations over power and resources by different actors (Jones and Zeng 2019, 1416). Hung (2015) conceptualizes China's current capital export regime as a consequence of a 'crisis of overaccumulation'. This is evident within the sectoral and geographical distribution of Chinese investments over the last two decades. Thus, the rise in Chinese aid provision to Africa and, more recently, Central Asia can be considered as part of an export-oriented development strategy led by the state-owned energy and construction sectors (Hung 2018, 2-3). Chen $(2018,44-45)$ similarly demonstrates that the heightened 'uneven regional development' between coastal and inland cities has resulted in the conceptualization of its foreign investments under the BRI as a spatial fix to address domestic developmental bottlenecks.

It is also crucial to refrain from a homogeneous understanding of different types of Chinese capital. While factors such as BRI policy goals, foreign aid, and OFDI are inevitably linked, their interactions manifest differently across different geographies. Abeliansky and Martínez-Zarzoso (2019) claim that while Chinese OFDI facilitates trade relations (a 10\% increase in FDI stocks in a country increasing its exports to China by an average of $2.1 \%$ ), the nature of the emergent trade relation is highly situation-specific. Moreover, the most significant determinant of trade relations facilitated by OFDI is the initial economic performance of the recipient country. In other words, Chinese OFDI in a developed economy is more likely to create beneficial trade relations than in developing economies. For the latter category, they argue, investment overwhelmingly falls under extractive industries (Abeliansky and Martínez-Zarzoso 2019, 2). Understanding FDI from China as the product of a unitary foreign policy is similarly problematic. In his analysis of Chinese investment in the Philippines, Camba (2020) identifies two distinct types of capital: statebacked capital and flexible capital. While the former imposes a specific developmental order, the latter attempts to unveil new avenues for accumulation and is more open to risk-taking. According to Du and Zhang (2018), a country's membership in the BRI increases its likelihood of receiving Chinese OFDI under sectors not directly linked to the initiative. They argue that investing in the BRI countries allows China's private sector to be eligible for support from the Chinese government and receive preferential treatment from the governments of recipient countries. However, while BRI membership positively impacts the likelihood of investment, 
the Chinese government has little influence over its non-SOE sectors. Thus, while Chinese SOEs in foreign countries tend to invest in infrastructure and energy, private firms' investments are context-dependent.

\section{The Political Economy of China-Turkey Relations}

Owing to the rising trade volume between China and Eurasian countries, its logistical vicinity to the European Union (EU), and the importance of Central Asia and the Caucasus for contemporary Chinese investment, Turkey rapidly came to be hailed as an important member of the Western Asia corridor of the BRI (Yildiran 2019). Following a series of mutual declarations of the importance of economic integration and signing a strategic cooperation agreement in 2010, Turkey's entry into the BRI was a significant step towards this goal (Chen 2020, 778). Historically, the overwhelming influence of the US and the EU on Turkish foreign policy prevented the development of a coherent regional policy towards the Asian continent. Subsequently, attempts at penetrating the sizeable Chinese market by the Turkish capital remained short-term and uncoordinated (Ergenç 2015, 297).

In the aftermath of the failed military coup on 15 July 2016, improving economic and political relationships with China gained urgency for Turkey's foreign policy. This period was marked by Turkey asserting itself more aggressively through its military involvement and coercive diplomacy in regional conflicts, as well as the acceleration of anti-EU and anti-US discourse of the ruling Justice and Development Party (Adalet ve Kalkınma Partisi) government led by President Recep Tayyip Erdoğan (Kutluay and Öniş 2021, 1091; Chen 2020). To this end, partnerships with countries that seemingly challenge Western liberal democratic values, such as China and Russia, were prioritized (Kutlay and Öniş 2021, 1093; Tao 2016, 24). Kutlay and Öniş (2021) argue that Turkey’s contemporary diplomacy based on 'assertive autonomy' is motivated by the Erdoğan administration's desire to consolidate its domestic support base. In other words, through its foreign policy activism in regional conflicts and over-emphasizing Turkey's role as a key regional and global player, Erdoğan appeals to the broad-based nationalist sentiments of the electorates at home. However, since Turkey's material capabilities do not meet this self-assertion, it remains mainly discursive, and the growing anti-Western sentiments voiced by the Turkish government on the international arena are not representative of actual policy-making (Kutlay and Öniş 2021, 1091). In 2020 Turkey's trade volume with EU and BRICS countries was around $\$ 143$ billion and $\$ 43$ billion, respectively (TÜIK 2021). Turkey's ongoing depth of economic integration with the EU and the US demonstrates the limitations of its geopolitical reorientation discourse (Tao 2016, 24-25). This warrants a level of caution in ascertaining the true extent of Sino-Turkish relations, as mutual proclamations of partnership might not be backed by robust economic and political cooperation (Ergenç 2015, 305). 
Nevertheless, Turkish officials have been adamant in expressing their optimism regarding the developmental potentiality of the country's involvement in the BRI (Parlar Dal 2017). By encouraging Chinese capital to invest in the Turkish economy, firms aspire to adopt technical know-how in energy (mainly solar and geothermal energy) and telecommunications (DEIK 2017, 2019; Dünya Gazetesi 2014). While emphasizing the strategic significance of these sectors for the Turkish economy is essential, the difficulty of pinning down the BRI to a specific set of policies or projects can result in over-fixating on a limited aspect of Chinese investment and attempting to reach macro conclusions. For example, while many studies examine Chinese aid in Africa, energy investments in Southeast Asia, and transportation projects in Central Asia, the economic, social, and developmental consequences of BRI membership for these regions are not limited to these sectors (Quer et al. 2015).

Although Turkey and China are both developing economies, their size and capacity are far from being equal. In 2018, China had the second-highest percentage share within the world GDP (at 16.83\%) (Trading Economics 2021). Moreover, given the sheer demographic size of China, which accounts for almost $20 \%$ of the world's population, its productive capacity is far greater, and its economic expansion is bound to have far-reaching consequences for global capitalism (Grell-Brisk 2017, 7 citing Arrighi 1994, 318). On the other hand, Turkey's GDP made up merely $0.91 \%$ of the world's GDP in the same year (Trading Economics 2021) and despite high levels of economic development during the early 2000s, it remains a much smaller economy both in size and capacity (Parnell et al. 2012, 92). Assessments of the Sino-Turkish economic relationship should take these differences into account.

According to the Ministry of Foreign Affairs in Turkey (Türkiye Cumhuriyeti Ticaret Bakanlığı 2021), Turkey’s imports from China amounted to almost \$113 billion over the last five years. In contrast, its exports to China amounted to \$13 billion during the same period, making China one of the biggest contributors to Turkey's current account deficit. In 2019, Turkey's import and export partner share percentage with China was $9.29 \%$ and $1.74 \%$, respectively (WITS 2020). During this period, Turkey's main imports from China were classified as 'electrical machinery and devices' and 'machines, mechanical devices, and tools', amounting to $\$ 5230$ million and $\$ 3887$ million, respectively. Mineral products constituted Turkey’s primary export product to China, with a total of $\$ 1320$ million (TCTB 2020, 13). As of 2020, Turkey had become the leading supplier of marble to China (Dünya Gazetesi 2020a; 2020c). The Central Bank of the Republic of Turkey (Türkiye Cumhuriyet Merkez Bankast, TCMB) reports that Turkish FDI stock in China totalled over \$66 million in 2019 (TCMB 2020). Atl (2020) notes that because TCMB only records capital officially registered as crossing the border from Turkey to mainland China, Turkish FDI in China is significantly undercounted. He estimates the actual Turkish FDI to China to be approximately $\$ 1$ billion. Nevertheless, even this upperbound estimate falls well below Turkish FDI in Western countries. In 2019, Turkish FDI stocks in the USA, the UK, the Netherlands and Austria were around \$3.2, $\$ 3.8, \$ 17.5$, and $\$ 2$ billion, respectively (TCMB 2020). 


\section{Chinese Investment in Turkey: A Critical Overview of Available Data}

The biggest problem in studying Chinese investment, particularly the BRI, is the lack of official and reliable data. In addition to the data published by international organizations, TCMB, the Foreign Economic Relations Board of Turkey (Dış Ekonomik Ilişkiler Kurulu, DEIK), the Ministry of Trade, and The Union of Chambers and Commodity Exchanges of Turkey (Türkiye Odalar ve Borsalar Birliği, TOBB), and the Turkish Statistical Institute (Türkiye Istatistik Kurumu, TÜİK) are the main sources publishing up-to-date data on the Turkish economy. Despite the primacy given to the Turkey-China economic relationship in recent years in Turkish official discourse, it has not been supported by making relevant data available, and existing data are often sparse and inconsistent. Although the Chinese embassy in Ankara reported that Chinese FDI stock in Turkey amounted to \$2.77 billion in 2019 (Atl 2020), the TCMB reported this number to be $\$ 1.18$ billion in the same year. According to the Ministry of Industry and Technology in Turkey, as of January 2021, it remained virtually unchanged at just over \$1 billion (TCSTB 2021). Official sources rank China as the 21st highest investor in Turkey, contributing only $0.6 \%$ of total FDI stock. Turkey's formal entrance to the BRI and the subsequent initiation of highly publicized BRI-affiliated projects have resulted in an unprecedented increase within the Chinese FDI flow to Turkey, from \$30 million in 2014 to its historical peak of $\$ 451$ million in 2015 (Figure 2). ${ }^{6}$ However, when Chinese FDI in Turkey is situated into the larger picture, one might argue that it is dwarfed by investments from other countries even at its highest point and that the volume of investment thus far has not been sustained.

There are three channels through which Chinese investment contributes to the Turkish economy. The first comprises of credits and loans disbursed by the Chinese government and banks for infrastructural development or on a project basis. From 2016 to the end of 2020, the Asian Infrastructural Investment Bank (AIIB) approved partial or complete financing of seven projects, totalling \$1.86 billion. These were geared towards infrastructure and capability development, including a COVID-19 relief credit amounting to $\$ 500$ million (AIIB 2021). The open-source dataset offered by AidData reports official financing from countries, development banks or organizations that do not participate in global reporting systems.

6. Two critical points with regards to the data necessitate further clarification. First is the sudden and dramatic drop in the FDI flow from China to Turkey after 2015. Although the climate of political instability in the aftermath of the attempted coup in July 2016 did not negatively affect Turkey's diplomatic relationship with China, the resulting economic instability caused considerable foreign capital flight from the Turkish economy (Chen 2020, 777-778). Moreover, many large-scale BRI-related investments in energy, transportation and banking sectors were initiated through Turkey's formal entry to the BRI in 2015. Thus, it is reasonable to expect a proportional increase in FDI flows from China to Turkey after these developments. Second is the vast discrepancy between FDI flow and FDI stock. While it is beyond the scope of this paper to scrutinize the specificities of the TCMB methodology, it should be noted that bilateral investments are not the sole source of FDI stock. Thus, these data do not account for offshore investments to existing operations, governmental loans and aid. 


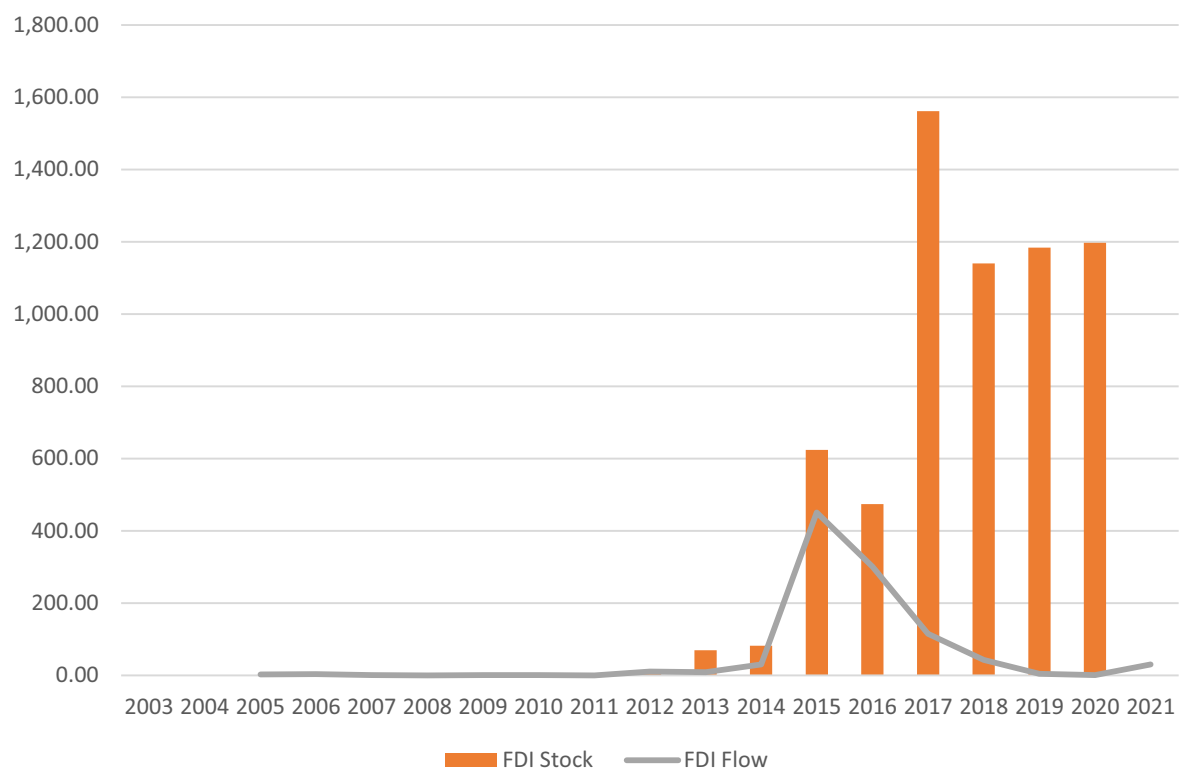

Figure 2. Chinese FDI stock in and FDI flow to Turkey (2002-2020, \$Million) Source: TCMB (2021)

According to their data, various Chinese institutions financed 12 projects in Turkey between 2002 and 2014. While nine of these projects were classified as either 'developmental' or 'representational', 7 three were 'mixed' (Dreher et al. 2017). The latter category, which amounts to $\$ 1.3$ billion in export credits, was used to construct Turkey's High-Speed Ankara-Istanbul Railway and for product purchasing and services from Huawei Technologies by Turk Telecom (Dreher et al. 2017). ${ }^{8}$ The existing data do not allow for conclusive inferences regarding the relative significance of loans, credits, and aid from China compared with other types of investments. However, it is nevertheless noteworthy that the bulk of the loans were geared towards publicized transportation and technology investments by a small number of Chinese firms with state backing. Hence, we need more research on small-tomedium-sized Chinese companies' activities in Turkey.

Investments are also made through greenfield investments and Mergers and Acquisitions (M\&A) deals by Chinese SOEs and the private sector. Greenfield investments refer to the building of subsidiaries by a company in a foreign country. Since it entails building operations from the 'ground-up', it holds potential for the generation of employment, transfer of technical know-how, and infrastructure

7. These were disbursed as one-off grants and were primarily used to respond to humanitarian aid in earthquake relief and to fund Confucius Institutes in Turkish universities.

8. It is worth mentioning that the Chinese smartphone firm ZTE purchased $48.8 \%$ of the shares of Turk Telecom in 2016 (Çolakoğlu 2021, 22). 
development (Yean 2018, 6). Recent examples include investments in production facilities and Research and Development (R\&D) institutes in Turkey by Chinese telecommunication and manufacturing firms Huawei, OPPO, and Haier (Anadolu News Agency 2021a; Dünya Gazetesi 2016; 2021a). Moreover, the Chinese electronics company Xiaomi has recently disclosed plans to open a production plant in Turkey. This venture's starting investment is said to be $\$ 30$ million and involves plans to open a factory with the capacity to produce five million phones per annum, generating over 2000 jobs (Cumhuriyet 2021). M\&A, on the other hand, refers to the partial or complete purchase of a domestic firm by a foreign investor (Gordon and Milhaupt 2019, 193). According to a report by the International Investors Association (Uluslararası Yatırımcılar Derneği, YASED), M\&A is rapidly becoming the most commonplace practice in the entry of Chinese capital to Turkey. In 2018, Chinese firms carried out the largest number and volume of M\&A deals with Turkish firms (accounting for 31\% of the national total), despite not ranking among the top ten countries in 2017 (Uluslararası Yatırımcilar Derneği 2019). These deals occur in a wide range of sectors. Notable examples from recent years include Ali Baba's acquisition of the Turkish retail company Trendyol (Atl 2020); deals making Chinese firms majority shareholders in the Yavuz Sultan Selim Bridge, the North Marmara Highway, and the Marmaray in Istanbul (all major transportation projects) (Akçay 2020); and the acquisition of Turkish Tekstilbank by the Industrial and Commercial Bank of China (ICBC) (Çolakoğlu 2021, 22).

According to the Chinese Investment Tracker by the AEI, there have been 27 investment and construction contracts with Turkey (amounting to \$15.96 billion) between 2005 and 2020. Energy, real estate, and transport sectors were the primary recipients of investments, with 14 , four and three contracts, respectively. The largest investment was in the energy sector ( $\$ 2400$ million) to construct a coal-fired power plant. The AEI dataset also records one 'troubled transaction' in the energy sector that was never finalized. The representation of the energy sector within the AEI data is consistent with existing accounts of Chinese investment in Turkey. However, the AEI only records investments over $\$ 100$ million, making it a valuable source for understanding the most ambitious investments but less helpful in illustrating the variability in private and small-scale investments. Moreover, it uses pledges from the Chinese government as its primary resource, resulting in exaggerated projections concerning Chinese FDI stock in other countries.

The relationship between FDI and economic growth for recipient countries has been a divisive subject in development scholarship. While the literature does suggest a strong link between the two, it has been argued that FDI does not necessarily bring about economic development. In other words, the direction of this causality is primarily determined by the initial conditions of the recipient economy, the macroeconomic context, and the type of investments made (Antwi et al. 2013; Blonigen and Wang 2004; Choe 2003; Li and Liu 2005). In order to ascertain the developmental potential of Chinese FDI in Turkey, we need to look more closely at the type of investments, sectoral distribution, and developmental potentials. 


\section{Data-Driven Analysis of Chinese OFDI in Turkey}

TOBB is the most reliable source of official data on firms in Turkey. In 2009, it took over TÜİK as the main official body publishing information about the opening and closure of firms in the country. Currently, it publishes monthly bulletins containing information about the different forms of organization, ownership patterns, specific activities, capital stock, and country information of firms operating in Turkey. However, TOBB's data are problematic. Rather than having a single dataset containing up-to-date information, the TOBB website only allows access to monthly bulletins. The sectoral and organizational classifications and scope of the information are not uniform and are susceptible to monthly alterations. For example, TOBB only began specifying the sectoral distribution of foreign capital investments and ownership percentages of foreign capital in 2017. The information disclosed in the bulletins merely discusses developments occurring during any particular month. This does not lend itself to an analysis of annual changes or the ability to gauge the overall picture of foreign ventures in Turkey. One exception to this is TOBB's publication of the complete list of firms with foreign capital operating in Turkey as of June 2019. However, this one-off publication contains only names, sectors, and country information and has not been updated since. The second problem concerns the provisional manner in which categorizations are made. Like AEI's data, TOBB's data merely discloses information on officially registered firms and therefore fails to provide an accurate sense of (a) the sectoral classification of investments, (b) whether/to what extent a specific investor is still active, (c) and the size and productivity of its operations.

We compiled our dataset of Chinese FDI in Turkey based on the 2019 TOBB report, which claims that by June 2019, there were a total of 1075 Chinese-invested firms operating in Turkey. We conducted a detailed online search on each firm and cross-checked their activities based on company websites, news reports, and registrations on local business directories. We were unable to identify any activity for 64 firms and therefore classified them as inactive and dropped seven firms whose names appear on TOBB's list more than once. We then identified 1004 firms in Turkey operating with Chinese capital. ${ }^{9}$ According to the data published by the Ministry of Industry and Technology, this number rose to 1148 in the first month of 2021 (TCSTB 2021). Table 1 shows the sectoral distribution of these firms. TOBB's list originally contained 43 sectors, and a closer inspection of the firms' activities revealed frequent false classifications. In order to make the data conducive for potential cross-country comparisons, 13 sectors were specified based on the existing literature (AEI 2020; Camba 2020; Hung 2018). Additionally, we created an 'Others' classification (Table 1). We also added a second identifier of value-added vs. non-value-added investments to better evaluate the potential contributions of these firms to industrial upgrading, R\&D and expansion of productive facilities. Value-creation refers to an 'activity that generates outputs worth more than their

9. Additional information on these firms was also included in the dataset when available. These included the year that the firm started its operations in Turkey, starting capital and employment generated. 
Table 1. Sectoral distribution of firms with Chinese capital in Turkey (June 2019)

\begin{tabular}{lcc}
\hline \hline Sectors & Number of firms & Percentage (\%) \\
\hline Wholesale and retail trade & 325 & 32.37 \\
Mining & 113 & 11.25 \\
Light manufacturing & 110 & 10.96 \\
Tours, hotels and entertainment & 97 & 9.66 \\
Manufacturing & 71 & 7.07 \\
Leasing and business services & 68 & 6.77 \\
Construction & 49 & 4.88 \\
Scientific research and technical services & 36 & 3.59 \\
Energy & 33 & 3.29 \\
Telecommunications and electricity & 32 & 3.19 \\
Transportation, storage and postal services & 27 & 2.69 \\
Real estate & 11 & 1.1 \\
Financial services & 5 & 0.5 \\
Other & 27 & 2.96 \\
Total & 1004 & \\
\hline \hline
\end{tabular}

Source: Authors' original dataset

input cost' (Mazzucato and Shipman 2014, 5). These entail investment in tangible assets and firms with expected (or existing) contributions to economic capacity, technical know-how, or industrial upgrading (Mazzucato and Shipman 2014, 4-5). Our list of companies making value-added investments includes manufacturing, construction, mining firms, and companies conducting on-the-ground scientific research and development in different sectors. Non-value-added investment, on the other hand, refers to the wholesale and retail of capital goods, subsidiaries of Chinese firms, and firms operating in the services sector. These ventures merely facilitate the sale of Chinese products in the Turkish market and offer minor technical assistance when necessary; they also offer storage, transportation, and distribution services for Chinese exports from and imports to Turkey. Based on our data, we found that as of June 2019, 55.3\% of firms with Chinese capital in Turkey had non-value-added, and $44.7 \%$ had value-added activities.

Chinese investors' high levels of non-value-added activities are consistent with Turkey's existing trade deficit with China. The 'wholesale and retail' sector constitutes the highest overall sector for investment with $32 \%$. This has two potential consequences for the Turkish economy. First, it entails considerable Chinese involvement in the domestic distribution network of imports from China. While this is not problematic in and of itself, second, and relatedly, the autonomy of Chinese subsidiaries in the distribution of imports can cause unfair competition for Turkish manufacturers in key sectors. Given that the main imports from China are electronics, the substantial activity in the wholesale and retail trade sector raises questions about Turkey as an emerging market for China's excess industrial capacity. Turkey's internal market is very small compared with China. However, over the last 
Table 2. The sectoral distribution of value-added investments by firms with Chinese capital in Turkey (June 2019)

\begin{tabular}{lcc}
\hline \hline Sector & Number of Firms & Percentage (\%) \\
\hline Light manufacturing & 110 & 27 \\
Mining & 108 & 27 \\
Manufacturing & 71 & 18 \\
Construction & 48 & 12 \\
Energy & 31 & 8 \\
Telecommunications and electricity & 13 & 3 \\
Scientific research and technical services & 8 & 2 \\
Financial services & 5 & 1 \\
Transportation, storage and postal services & 4 & 1 \\
Leasing and business services & 4 & 1 \\
Tours, hotels and entertainment & 2 & 0 \\
Real estate & 0 & 0 \\
Total & 404 & \\
\hline \hline
\end{tabular}

Source: Authors' original dataset

few years, Turkish manufacturers in the energy and construction sectors have voiced their concerns over the alleged 'dumping' of Chinese equipment and materials to the Turkish market (Dünya Gazetesi 2015a; 2015b; 2021b; Anadolu News Agency 2019; 2021b). The 2021 communiqué on the prevention of unfair competition of imports by Turkey's Ministry of Commerce discussed the possibility of decreased profitability of domestic production in automobile engines due to Chinese imports and called for an investigation of dumping practices (Resmi Gazete 2021).

A closer examination of the sectoral distribution of value-added investments, on the other hand, yields significant insights regarding the potential of Chinese capital to bring about industrial upgrading and transfer of technical know-how to Turkey (Table 2). Light manufacturing and mining are the sectors containing the largest number of Chinese-invested firms in this category. Light manufacturing refers to low-value-added products such as textiles, minimally processed agricultural products, and basic industrial intermediary products. Most of China's value-added investment in Turkey are reflective of its import interests since, over the last decade, China has begun to import primary and basic intermediary goods such as marble and paper products (Dünya Gazetesi 2020b). Atlı (2017) notes that marble exports to China mainly come from Chinese-owned stopes with minimal processing capacities in Turkey. Thus, China's domestic economic demands are well-represented in the distribution of its OFDI in Turkey. Almost half of the firms classified as 'light manufacturing' specialize in textiles (the manufacturing of garments, production of cloth and thread, and the processing of leather and fur). The increase in the wage levels within the Chinese manufacturing sector over the last decade, in tandem with the decrease in Turkey's real wages, has resulted in a relative convergence in the 
respective countries' relative labour cost. Although wage rates demonstrate significant geographical variability within China, in 2018, the hourly minimum wage rate in Beijing (which is the city with the highest hourly minimum wage) was $\$ 3.19$ (China Briefing 2021). In the same year, the hourly minimum wage in Turkey was $\$ 5.27$ (ILO 2021). Thus, currently, labour cost cannot account for the significant gravitation towards low-value-added and labour-intensive activities of Chinese capital in Turkey. Although further inquiry is necessary for explaining this trend, Turkey's proximity to the EU and CEE countries is one possible explanation. In other words, Chinese capital could use Turkey's relatively low cost of labour to become more competitive in the European market. Regardless of Chinese motivations, since most 'value-added' activities within the wholesale and retail sector refer to the minimal processing, packaging, and assembly of capital goods, their potential contribution to industrial upgrading is limited.

As these data only represent the sectoral gravitation of Chinese capital, it should not be mistaken for the volume of OFDI. However, a close examination of the sectoral distribution of Chinese-invested firms reveals a discrepancy between different types of overseas capital movements. The fact that sectors such as energy, manufacturing and construction occupy $7 \%, 16 \%$ and $11 \%$ (respectively) of Chinese-invested firms with value-added operations is consistent with the official discourse on Turkey's participation in the BRI. However, most Chinese-invested firms in Turkey remain non-value-added, and the firms with productive capabilities are clustered in sectors aiming to either extract natural resources or produce minimally processed products. The high number of mining firms in particular points to China's increasing effort to secure the supply of raw materials.

Table 3 shows the yearly distribution of the opening of Chinese-invested firms in Turkey, their initial capital investment, and the average percentage of Chinese ownership within these ventures. Between 2011 and 2020, Chinese capital was the majority shareholder in most joint ventures (Table 3), suggesting a greater autonomy of Chinese capital in these firms. This is important because Chineseinvested firms and projects abroad have been criticized for their tendency to hire Chinese labour in their operations and thereby fail to contribute to job creation in recipient countries (Benabdallah 2019). Two in-depth studies on the labour practices in BRI projects in Africa have debunked this criticism by showing that in all operations analysed, the majority of the labour force was of local origin (Chiyemura 2020; Oya and Schaefer 2019). However, these works have also demonstrated that ascertaining the dominant hiring practices of Chinese firms with private vs. state-backed capital were largely inconclusive (Oya and Schaefer 2019, 16-17) and that the tendency to hire Chinese labour does increase at the upper echelons of the labour hierarchy. In other words, Chinese firms tend to source skilled labour in their overseas operations internally, which does not raise optimism for industrial upgrading in recipient countries. Finally, it is worth mentioning that the capital specified here represents initial investment only and does not account for additional actions. 
Table 3. The annual breakdown of Chinese capital investment in Sino-Turkish joint ventures $(2011-2020)^{10}$

\begin{tabular}{lcccc}
\hline \hline Year & $\begin{array}{c}\text { Number of } \\
\text { firms }\end{array}$ & $\begin{array}{c}\text { Total amount } \\
\text { of capital } \\
\text { in joint ventures } \\
\text { (USD) }\end{array}$ & $\begin{array}{c}\text { Amount of Chinese } \\
\text { capital in joint ventures } \\
\text { (USD) }\end{array}$ & $\begin{array}{c}\text { Percentage } \\
\text { of Chinese } \\
\text { ownership } \\
(\%)\end{array}$ \\
\hline 2011 & 49 & $\$ 8.428 .186,27$ & $\$ 5.844 .395,22$ & 69 \\
2012 & 47 & $\$ 6.358 .491,09$ & $\$ 4.032 .850,78$ & 63 \\
2013 & 73 & $\$ 58.009 .453,78$ & $\$ 56.059 .453,78$ & 97 \\
2014 & 89 & $\$ 70.455 .002,28$ & $\$ 67.960 .027,41$ & 96 \\
2015 & 84 & $\$ 19.207 .720,59$ & $\$ 14.617 .211,40$ & 76 \\
2016 & 72 & $\$ 5.710 .264,90$ & $\$ 4.462 .225,17$ & 78 \\
2017 & 54 & $\$ 3.562 .369,79$ & $\$ 3.073 .252,47$ & 86 \\
2018 & 87 & $\$ 11.135 .874,07$ & $\$ 8.509 .918,19$ & 76 \\
2019 & 115 & $\$ 14.010 .398,31$ & $\$ 11.272 .188,93$ & 80 \\
2020 & 75 & $\$ 7.852 .924,63$ & $\$ 6.119 .417,89$ & 77 \\
Total & 745 & $\$ 204.730 .685,72$ & $\$ 181.950 .941,23$ & 80 \\
\hline \hline
\end{tabular}

Source: Authors' own calculations based on Türkiye Odalar ve Borsalar Birliği (TOBB) (2021)

\section{The Sino-Turkish Economic Integration under the BRI in Comparative Perspective}

Comparing the Turkish experience with countries from the CEE (Hungary and Serbia) and MENA (Egypt and Israel) regions will better situate contemporary Sino-Turkish relations into the larger context of Chinese global investments. Except for Israel, a high-income country, all other countries are classified by the World Bank as located in different zones of the group of 'middle-income countries'. ${ }^{11}$ Thus, an analysis of their respective integrations with China can reveal crucial insights into the country-specific policies of Chinese capital in key sub-regions of the BRI.

In 2016, the CEE countries received $0.12 \%$ of Chinese OFDI stock and merely $1.92 \%$ of the Chinese OFDI in Europe (Ramasamy and Yeung 2020, 2). The central political cooperation among China and CEE countries is through the $17+1$ Initiative. This agreement, signed in 2012, is aimed at the construction of a regional cooperation mechanism between China and CEE and to mutually contribute to investment flows and development (Brînză 2019, 214). Unlike the other countries from the region, both Serbia and Hungary have been enthusiastic partners of

10. Due to the limited information disclosed by TOBB (2021), this table merely demonstrates the number of firms that were formed or acquired by Chinese capital from 2011 onwards. Subsequently, the list does not account for firms that started their operations before 2011.

11. The GDP per capita of these countries in 2019 were as follows: Egypt (\$3019), Hungary $(\$ 16,731)$, Israel (\$43,592), Serbia (\$7411), and Turkey (\$9126) (World Bank, n.d.). Hence, while Egypt is located at the lower bound of the middle-income countries bordering low-income nations, Hungary is located at the upper bound, bordering rich nations. Serbia and Turkey are similarly located in the middle of these two rungs. 
China before the initiation of $17+1$ and had established bilateral ties over the last two decades (Jacoby 2014, 201; Vučić 2020, 339). Despite this ongoing cooperation, however, Serbia and Hungary occupy different spaces regarding the level and sectoral distribution of Chinese investments at the current juncture.

In addition to gaining accession to the EU, establishing strong economic relationships with powerful actors such as the US, Russia, and China has been a foreign policy priority for Serbia in recent years (Vučić 2020, 338). Despite the Serbian government's overt developmental expectations from China in terms of industrial capacity building, the Sino-Serbian cooperation in the last decade 'has been characterized by mutual asymmetry in all economic parameters' (Dimitrijević 2017, 70). In 2020, Serbian exports to and imports from China were $\$ 377.03$ million and $\$ 3.29$ billion, respectively (WITS 2020). Since the initiation of the $17+1$, China has pledged over $\$ 1$ billion to Serbia, mainly in loans to finance the building of transport and energy infrastructure. To date, the most important Chinese investment in Serbia has been the acquisition of a steel plant in Smederevo by the Hebei Iron and Steel Company for $€ 46$ million (Vučić 2020, 344). This M\&A deal has increased the Serbian GDP by 1\% (Dimitrijević 2017, 76). Nevertheless, recent scholarship has questioned China's ability to contribute to its economy substantially. The main reasons for this scepticism are (a) Serbia's large trade deficit with China, (b) the size and frequency of investments compared with EU countries and the US, and (c) investments being channelled chiefly through state-to-state loans by providing state guarantees. The latter aspect, in particular, puts the profitability of Chinese OFDI for Serbia into question (Dimitrijević 2017, 77).

Hungary, on the other hand, has received one of the highest shares of Chinese OFDI stock among the CEE (18.8\%), after Romania (23.5\%) and Poland (19.3\%) in 2016 (Ramasamy and Yeung 2020, 2). Investment has mainly flowed into the manufacturing sector, focusing on the assembly of industrial products (Éltetö 2016, 34). In recent years, automotive, renewable energy, services - especially in Business Processing Outsourcing (BPO) - and chemicals sectors have increasingly attracted Chinese capital (Völgyi and Lukács 2021, 168). The largest Chinese investment to the CEE and the most significant contributor to Chinese OFDI stock in Hungary is Wanhua's acquisition of $96 \%$ of the Hungarian chemical company BorsodChem. Hungary has also benefited from its inclusion in the global production networks of large (partially or entirely) Chinese-owned companies, such as Huawei, Lenovo, and BYD electronics (Szunomár and Peragovics 2019, 5). Among other countries of the region, the main attribute that sets Hungary apart is a uniform strategy towards the encouragement of investors from China by introducing special incentives and expediting the entry of the Chinese banks and law firms to Hungary (Éltető 2016, 34-35).

The geographical significance of the MENA region for the maritime and landline projects under the BRI is undeniable. However, in 2016, this region only made up $1.58 \%$ of Chinese OFDI stock (Ramasamy and Yeung 2020, 2). Unlike the CEE region, there ceases to be a common framework to analyse and understand contemporary Chinese economic integration with Egypt and Israel. Despite both being BRI 
members, the composition of the two countries' economies entails that Chinese investments' determinants and contexts are vastly different. The main factors facilitating the intensification of economic cooperation between Egypt and China is the former's geopolitical significance for the BRI, the size of its domestic market, and its proximity to key trade partners of China in Africa and Europe (Elshamy 2017, 194). Through the 'Comprehensive Strategic Partnership' in 2014, the two countries pledged to intensify their existing integration further through signing a framework agreement of 15 projects worth $\$ 10$ billion in loans and OFDI (Chaziza 2021, 258-259). In 2016, a memorandum of understanding was signed, which included $\$ 15$ billion in 'deals relating to electricity, energy, finance, infrastructure, technology, and space as well as \$1.7 billion in loans for Egyptian financial institutions' (Chaziza 2021, 259). There are three main drivers of Egyptian interest in Chinese investment. First, Egypt wants to decrease its economic dependency on the EU and the US. While China surpassed the US and became Egypt's largest trade partner from 2012 onwards (Chaziza 2021, 261), in 2016, the EU was the main source of FDI stock in Egypt (Elshamy 2017, 190). The Egyptian government has been vocal about its desire for an economic partner that does not interfere in its domestic politics. Second, Egypt lacks the institutional conditions for receiving a large amount of Western FDI and loans, and seeking Chinese investment is viewed as a way of circumventing a comprehensive reform of its financial system. Lastly, Chinese contracting in the Suez Canal Economic Zone (SCE Zone) is believed to have the capacity to generate jobs and help Egypt reduce its severe unemployment problem (Chaziza 2021, 260). However, Chinese investment in Egypt remains modest outside of the SCE Zone. In 2018, 1459 Chinese companies were active in Egypt with around $\$ 610$ million in investment. The percentage shares of industrial projects, finance, and communications and information technology were $68 \%, 15 \%$, and $9 \%$, respectively, providing a total of only 27,566 jobs (Metwally 2018).

The Chinese investment portfolio in Israel is entirely different from that in Egypt. From 1992 to 2018, the bilateral trade volume between China and Israel increased from $\$ 50$ million to $\$ 13.9$ billion, making China Israel's third-largest trade partner after the EU and the US (Harutyunyan 2020, 411). Unlike the countries examined thus far, however, Israel's main imports from China have historically been raw materials, consumer goods, and textile products. In contrast, its key exports have 'consisted of high-tech products, including electronics, optical, agricultural and water technologies, chemical industry, and communications' (Harutyunyan 2020, 412). According to the Global Innovation Rankings, Israel has a higher track record in innovation than China (Peled and Harpaz 2018, 9). Since China has one of the leading manufacturing markets in the world, improving its innovation capacity has been a crucial priority for its domestic economy (Harutyunyan 2020, 412). Chinese investment in Israel in the last decade has covered almost all emerging sectors in technology and industry either through investments or by funding targeted research centres (Harutyunyan 2020, 419). In 2018, Chinese investment made up 12\% of all investments in start-ups and over 25\% in large-scale start-up investments (over \$25 million) in Israel. While the contributions of the arms trade and investment are omitted from 
the reports, in 2018, more than 1000 companies with Chinese capital were active in Israel and $20 \%$ of all investments made in hi-tech companies belonged to China (Harutyunyan 2020, 420).

This brief overview of Chinese investment in Serbia, Hungary, Egypt and Israel reveals the critical importance of accessing reliable and uniform data for cross-country comparisons. Much like the Turkish case, the main shortcomings of the available data are (a) vast differences in Chinese OFDI reports according to different sources (Szunomár and Peragovics 2019); (b) the inability of the figures to account for Chinese offshore investments (Völgyi and Lukács 2021; Dimitrijević 2017); (c) differences between pledged and invested capital (Elshamy 2017); and (d) the omission of sectors such as the arms trade from reports (especially for Israel) (Harutyunyan 2020). Although we will draw provisional conclusions below based on the discussion above, future case studies on Chinese OFDI could benefit from data-driven analyses such as the one we have done for this article.

An unsurprising trend that emerges across the board is that all countries examined here run a substantial trade deficit with China in a similar vein to Turkey. The import of electronics and machinery from Serbia, Hungary, and Egypt suggests that China engages in market-seeking behaviour for its excess industrial capacity. However, the trajectory of Chinese trade relations with Israel reveals that, despite being a leading manufacturer of advanced technological appliances, it nevertheless does import equipment from high-income countries where innovation is more advanced. Moreover, the composition of Chinese exports to Israel also demonstrates that raw materials and minimally processed capital goods continue to be an essential source of revenue for the Chinese economy. As a high-income country with important developments in hi-tech sectors, Israel receives a disproportionate number of value-added investments from China. However, in 2018, Chinese FDI stock constituted merely $2.93 \%$ of total FDI stock in Israel, a very low figure compared with the US FDI stock (20.49\%). ${ }^{12}$ Moreover, the US often co-develops innovation with Israel, giving them veto power over their transfer (Peled and Harpaz 2018, 29). Thus, the growth of investment in sectors with strategic importance for Chinese interest is vulnerable to and limited by the US influence in Israel.

The discrepancy between the projections for Chinese investment and the ground realities in countries other than Israel is similar to Turkey's experience. Despite the overt developmental expectations from China, their strategic proximity to the European market, and relatively low cost of labour compared with neighbouring states, Chinese investments to Serbia and Hungary have occurred through either the acquisition of existing companies by Chinese capital or the opening of operations by large Chinese firms, such as Huawei of Lenovo. Channelling investments through a limited number of large-scale firms could substantially harm the receiving countries' economies if investing companies decide to relocate elsewhere (Szunomár and Peragovics 2019). Although Chinese investments in these countries have included value-added sectors such as manufacturing, telecommunications and 
electricity, and scientific research and technical services, these (a) have not been comparable with EU or US investments, either in substance or volume (Jacoby 2014), and (b) were largely limited to low-value-added activities such as assembly and BPO. Finally, compared with these countries, Egypt has been much less successful in attracting value-added investment from China.

\section{Conclusion}

China has only recently become a middle-income country and is currently pursuing a strategy of technological upgrading and innovation to amass wealth over the coming decades. Its capacity to contribute to the economic development of other countries has increased. However, Chinese investments primarily serve its pursuit of upward mobility in the world economy rather than the elevation of other countries. The BRI has emerged as a powerful policy tool in facilitating Chinese-led international cooperation, but its effects on the domestic economies of participating countries are bound to exhibit significant variation. Since Chinese investment funds are limited, some participating countries may attract development-generating investment from China while others may not. Hence, the diverse types of Chinese capital operating across BRI countries should be carefully distinguished.

Although academic and policy literature on Sino-Turkish economic relations have grown after Turkey's inclusion in the BRI, the existing scholarship lacks data on different types of Chinese investment in Turkey. Based on an original dataset and a variety of secondary sources, this article shows that while Chinese investment in Turkey has increased considerably in recent years, it remains quite modest compared with investments from Western countries. Moreover, despite the expanding activities of Chinese technology companies, our dataset shows that most Chinese investment in Turkey remains non-value added. On the other hand, the value-added investments are in low-productivity and low-skilled sectors and reflect demands made by China's domestic import interests in Turkey. Our comparison of Turkey with Egypt, Serbia, Hungary, and Israel reveals similar trends. Much as in Turkey, Chinese OFDI in Serbia, Hungary, and Egypt have failed to meet expectations from local actors in terms of their diversification, volume, and contribution to local capacity building in a substantial manner. In contrast, Israel's high-income country status has encouraged Chinese investment toward high-tech/high value-added sectors. Despite such investment activity, however, Chinese companies have failed to break the overwhelming influence of the American companies in Israel. This situation is similar to what we have so far observed in Turkey regarding Chinese versus European capital.

We cannot rule out the possibility of a dramatic increase in China's involvement in the Turkish economy in the coming years. Over the last two years, for instance, Chinese banks, companies, and officials have actively pursued involvement in the politically controversial İstanbul Canal project, an artificial sea-level waterway connecting the Black Sea and the Mediterranean Sea (Akçay 2020; Özgentürk 2021). 
The project's future remains uncertain, but if it involves Chinese investment, China will quickly become a major player in the Turkish economy. Still, such an event would not change the developmental capacity of Chinese investment. The construction of giant canals on their seaways did not improve the position of Egypt and Panama in the world economy, so there is no reason to think otherwise of the İstanbul Canal project. Attracting a sizeable volume of development-enhancing investment from China will require a structural transformation of the Turkish political economy toward a more technology-intensive and innovation-driven direction aimed at upward mobility in the world economy. In other words, in order to attract a meaningful amount of development-generating Chinese investment, Turkey would need to follow a path similar to the one that China and other East Asian countries have taken over several decades. Turkey has never become an East Asian-type developmentalist state, and a reorientation of this kind is not looming on today's horizon.

\section{Acknowledgements}

We thank three reviewers for European Review for their helpful critiques and suggestions. We also thank Hao Qi for giving useful feedback on an early version of the manuscript. The KU-Renmin Seed Fund supported our research.

\section{References}

Abeliansky AL and Martínez-Zarzoso I (2019) The relationship between the Chinese 'going out' strategy and international trade. Economics 13(1), https://doi.org/10. 5018/economics-ejournal.ja.2019-21

Akçay N (2020) Kanal İstanbul'da olası bir Çin finansörlüğü ve barındırdığı riskler. Independent Türkçe. 1 January 2020. Available at https://www.indyturk.com/ node $/ 111476 / \mathrm{t} \% \mathrm{C} 3 \%$ BCrkiyeden-sesler $/$ kanal-istanbul $\% \mathrm{E} 2 \% 80 \% 99$ da-olas $\% \mathrm{C} 4 \%$ B1-bir- $\%$ C3 $\%$ A 7 in-finans $\% \mathrm{C} 3 \% \mathrm{~B} 6 \mathrm{rl} \% \mathrm{C} 3 \% \mathrm{BC} \% \mathrm{C} 4 \% 9 \mathrm{~F} \% \mathrm{C} 3 \% \mathrm{BC}$-ve-bar $\% \mathrm{C} 4 \%$ $\mathrm{B} 1 \mathrm{nd} \% \mathrm{C} 4 \% \mathrm{~B} 1 \mathrm{rd} \% \mathrm{C} 4 \% \mathrm{~B} 1 \% \mathrm{C} 4 \% 9 \mathrm{~F} \% \mathrm{C} 4 \% \mathrm{~B} 1$-riskler (accessed 10 March 2021).

Akdağ Z (2019) Türkiye-Çin İlişsilerinde Kuşak ve Yol Girişimi’nin Önemi. Birey ve Toplum Sosyal Bilimler Dergisi 9(1), 65-96, https://doi.org/10.20493/birtop. 558276.

American Enterprise Institute (AEI) (2020) China Global Investment Tracker. Washington, DC: AEI. Available at https://www.aei.org/china-global-investmenttracker/ (accessed 04 April 2021).

Anadolu News Agency (2019) Çin'den gelen alüminyum içeren ürünlere damping incelemesi. Istanbul: AA. Available at https://www.aa.com.tr/tr/ekonomi/cindengelen-aluminyum-iceren-urunlere-damping-incelemesi/1488760 (accessed 27 July 2021).

Anadolu News Agency (2021a) Akıllı telefon üreticisi OPPO, Türkiye'de test üretimine başladl. Istanbul: AA. Available at https://www.aa.com.tr/tr/turkiye/ akilli-telefon-ureticisi-oppo-turkiye-de-test-uretimine-basladi/2168118 (accessed 1 March 2021).

Anadolu News Agency (2021b) Çin'den ithal 'gücü 15 kilovatı geçmeyen dizel motorlara' yönelik damping soruşturması başlatıldı. Istanbul: AA. Available at 
https://www.aa.com.tr/tr/ekonomi/cinden-ithal-gucu-15-kilovati-gecmeyen-dizelmotorlara-yonelik-damping-sorusturmasi-baslatildi/2194742 (accessed 27 July 2021).

Antwi S, Mills E, Mills GA and Zhao X (2013) Impact of foreign direct investment on economic growth: Empirical evidence from Ghana. International Journal of Academic Research in Accounting, Finance and Management Sciences 3(1), $18-25$.

Arrfat Y (2020) Aligning the global value chains of China and Pakistan in the context of the Belt and Road Initiative, and China Pakistan Economic Corridor. In Syed J, Ying, Y-H (eds), China's Belt and Road Initiative in a Global Context Volume I: A Business and Management Perspective. Switzerland: Springer, pp. 203-226.

Arrighi G (ed.) (1994) The Long Twentieth Century: Money, Power, and the Origins of Our Times, 2nd Edn. London: Verso.

Asian Infrastructure Investment Bank (AIIB) (2021) Our Projects. Beijing: AIIB. Available at https://www.aiib.org/en/projects/list/index.html (accessed 10 March 2021).

Atlı A (2017) China's growing appetite for Turkish marble. Asia Times, 21 July 2017. Available at https://asiatimes.com/2017/07/chinas-growing-appetite-turkishmarble/ (accessed 2 February 2021).

Atlı A (2019a) Turkey's economic expectations from a rising China. In Erşen E and Köstem S (eds), Turkey's Pivot to Eurasia: Geopolitics and Foreign Policy in a Changing World Order. London: Routledge, pp. 79-92.

Atlı A (2019b) Türkiye'nin Çin ile Ekonomik İlişkilerinde Denge Arayışları. In Yağc1 M and Bakır C (eds), Çin Bilmecesi: Çin'in Ekonomik Yükselişi, Uluslararast Ilişskilerde Dönüşüm ve Türkiye. Istanbul: Koc Universitesi Yayinlari, pp. 143-162.

Atl A (2020) Turkey, China and the Belt and Road Initiative: Expectations of Increasing Economic Interdependence. Istanbul: Koc University Center for Asia Studies Webinar Series.

Bandiera L and Tsiropoulos V (2020) A framework to assess debt sustainability under the Belt and Road Initiative. Journal of Development Economics 146, 102495, https://doi.org/10.1016/j.jdeveco.2020.102495.

Benabdallah L (2019) Contesting the international order by integrating it: The case of China's Belt and Road initiative. Third World Quarterly 40(1), 92-108, https:// doi.org/10.1080/01436597.2018.1529539

Blonigen BA and Wang M (2004) Inappropriate pooling of wealthy and poor countries in empirical FDI studies. NBER Working Papers 10378, National Bureau of Economic Research.

Brautigam D (2020) A critical look at Chinese 'debt-trap diplomacy': The rise of a meme. Area Development and Policy 5(1), 1-14, https://doi.org/10.1080/23792949. 2019.1689828

Brînză A (2019) The '17+ 1' mechanism: caught between China and the United States. China Quarterly of International Strategic Studies 5(2), 213-231.

Caixin Global (2018) China's Murky Lending is Making Sub-Saharan Africa More of a Credit Risk, Moody's Says. 15 November 2018. Available at https://www. caixinglobal.com/2018-11-15/chinas-murky-lending-is-making-sub-saharan-africamore-of-a-credit-risk-moodys-says-101347630.html (accessed 01 April 2021).

Camba A (2020) The Sino-centric capital export regime: state-backed and flexible capital in the Philippines. Development and Change 51(4), 970-997, https://doi. org/10.1111/dech.12604 
Camba A and Hung HF (2018) China, Africa, and global economic transformation. In Alden C and Large D (eds), New Directions in Africa-China Studies, London: Routledge, pp. 318-331.

Carmody P (2020) Dependence not debt-trap diplomacy. Area Development and Policy 5(1), 23-31. https://doi.org/10.1080/23792949.2019.1702471

Chaziza M (2021) Egypt in China's maritime Silk Road Initiative: relations cannot surmount realities. In China's Maritime Silk Road Initiative, Africa, and the Middle East (pp. 255-283). Singapore: Palgrave Macmillan.

Chellaney B (2017) China's Debt-Trap Diplomacy. Project Syndicate. Available at https://www.project-syndicate.org/commentary/china-one-belt-one-road-loansdebt-by-brahma-chellaney-2017-01?barrier=accesspaylog (accessed 21 April 2021).

Chen X (2018) Globalisation redux: can China's inside-out strategy catalyse economic development and integration across its Asian borderlands and beyond? Cambridge Journal of Regions, Economy and Society 11(1), 35-58, https://doi. org/10.1093/cjres/rsy003

Chen X and Fazilov F (2018) Re-centering Central Asia: China's 'new great game' in the old Eurasian heartland. Palgrave Communications 4(1), 1-12.

Chen Y (2020) Developments in China-Turkey relations: a view from China. Critical Sociology 46(4-5), 777-787.

Chen Y (2021) Laying the tracks: the political economy of railway development in Ethiopia's railway sector and implications for technology transfer. Global Development Policy Center, GCI Working Paper 014. Available at https://www. bu.edu/gdp/files/2021/01/GCI_WP_014_Yunnan_Chen.pdf (accessed 10 February 2021).

Chernysheva NA, Perskaya VV, Petrov AM and Bakulina AA (2019) Green energy for belt and road initiative: economic aspects today and in the future. International Journal of Energy Economics and Policy 9(5), 178-185.

China Briefing (2021) A Guide to Minimum Wages in China in 2021. 22 June 2021. Available at https://www.china-briefing.com/news/minimum-wages-china-2021/ (accessed 27 July 2021).

ChinaPower (2021) How will the Belt and Road Initiative advance China's interests? ChinaPower Project. Available at http://chinapower.csis.org/china-belt-and-roadinitiative/ (accessed 5 April 2021).

Chiyemura F (2020) Contextualizing African agency in Ethiopia-China engagement in wind energy infrastructure financing and development, IKD Working Paper No. 88, Milton Keynes: The Open University.

Choe JI (2003) Do foreign direct investment and gross domestic investment promote economic growth? Review of Development Economics 7(1), 44-57.

Colakoğlu S (2021) China in the Broader Black Sea Region. GLOBSEC. Available at https://www.globsec.org/publications/china-in-the-broader-black-sea-region/ (accessed 5 April 2021).

Cumhuriyet (2021). Erdoğan'dan Xiaomi açıklaması. Istanbul: Cumhuriyet Gazetesi. Available at https://www.cumhuriyet.com.tr/haber/erdogandan-xiaomi-aciklamasi1824032 (accessed 5 April 2021).

Dimitrijević D (2017) Chinese investments in Serbia - a joint pledge for the future of the New Silk Road. Baltic Journal of European Studies 7(1), 22.

Dış Ekonomik İlișkiler Kurulu (DEIK) (2017) Türkiye ve deniz ipek yolu çalıştayı. Istanbul: DEIK. Available at https://deik.org.tr/basin-aciklamalari-turkiye-vedeniz-ipek-yolu-calistayi (accessed 5 April 2021).

Dış Ekonomik İlişkiler Kurulu (DEIK) (2019) Çin 2021'e kadar Türkiye'deki yatırımlartnı ikiye katlamayı hedefliyor. Istanbul: DEIK. Available at https:// 
deik.org.tr/basin-aciklamalari-cin-2021-e-kadar-turkiye-deki-yatirimlarini-ikiyekatlamayi-hedefliyor (accessed 5 April 2021).

Deng F, Wang Y, Li Z, and Liang X (2020) China's technology spillover effects in the countries along the Belt and Road - evidence from 49 BRI countries. Applied Economics 52(51), 5579-5594.

Dreher A, Fuchs A, Parks BC, Strange AM and Tierney MJ (2017) Aid, China, and growth: evidence from a new global development finance dataset. AidData, Working Paper \#46.

Du J and Zhang Y (2018) Does one belt one road initiative promote Chinese overseas direct investment? China Economic Review 47, 189-205.

Dünya Gazetesi (2014) Türk bilişimciler Çin'de 'uzman'laştı. 15 December 2014. Available at https://www.dunya.com/sirketler/turk-bilisimciler-cin039de039uzman039lasti-haberi-266741 (accessed 5 April 2021).

Dünya Gazetesi (2015a) Yerli güneş paneline Çin'e karşı koruma isteniyor. 18 February 2015. Available at https://www.dunya.com/sektorler/enerji/yerli-gunes-panelinecin039e-karsi-koruma-isteniyor-haberi-271642 (accessed 27 July 2021).

Dünya Gazetesi (2015b) Demir-çelik ithalatında Çin tehdidi büyüyor. 10 May 2015. Available at https://www.dunya.com/ekonomi/demir-celik-ithalatinda-cin-tehdidibuyuyor-haberi-279404 (accessed 27 July 2021).

Dünya Gazetesi (2016) Huawei, Türkiye odakl büyümeye devam edecek. 29 December 2016. Available at https://www.dunya.com/sirketler/huawei-turkiyeodakli-buyumeye-devam-edecek-haberi-343705 (accessed 5 April 2021).

Dünya Gazetesi (2020a) Türkiye'nin en büyük madencilik ürünleri alıclsı Çin oldu [Text]. 14 October 2020. Available at https://www.dunya.com/sektorler/ madencilik/turkiyenin-en-buyuk-madencilik-urunleri-alicisi-cin-oldu-haberi-485239 (accessed 5 April 2021).

Dünya Gazetesi (2020b) Türkiye’nin Çin'e yaptı̆̆l kağlt ve kağlt ürünleri ihracatı yüzde 216 arttl. 15 October 2020. Available at https://www.dunya.com/ ekonomi/turkiyenin-cine-yaptigi-kagit-ve-kagit-urunleri-ihracati-yuzde-216-arttihaberi-485371 (accessed 5 April 2021).

Dünya Gazetesi (2020c) Bakan Pekcan'dan Çinli firmalara Türkiye’de yatırım çağrısı. 6 December 2020. https://www.dunya.com/ekonomi/bakan-pekcandan-cinlifirmalara-turkiyede-yatirim-cagrisi-haberi-472564 (accessed 5 April 2021).

Dünya Gazetesi (2021a) Çinli Haier'den Eskişehir'e 40 milyon Euro'luk yatırımDünya Gazetesi. 4 February 2021. Available at https://www.dunya.com/ sirketler/cinli-haierden-eskisehire-40-milyon-euroluk-yatirim-haberi-609689 (accessed 5 April 2021).

Dünya Gazetesi (2021b) Çin ithal ürünlere karşı önlem alıyor. 24 March 2021. Available at https://www.dunya.com/dunya/cin-ithal-urunlere-karsi-onlem-aliyorhaberi-615530 (accessed 27 July 2021).

Elshamy H (2017) The Economic Determinants of Chinese Foreign Direct Investment in Egypt. In China and Africa. Cham: Palgrave Macmillan.

Éltetö A (2016) Chinese investment and trade strengthening ties with Central and Eastern Europe. International Journal of Business and Management 4(1), 24-48.

Ergenç C (2015) Can two ends of Asia meet? An overview of contemporary TurkeyChina relations. East Asia 32(3), 289-308.

Flint C and Zhu C (2019) The geopolitics of connectivity, cooperation, and hegemonic competition: The Belt and Road Initiative. Geoforum 99, 95-101.

Fon RM, Filippaios F, Stoian C and Lee SH (2021) Does foreign direct investment promote institutional development in Africa? International Business Review 101835. https://doi.org/10.1016/j.ibusrev.2021.101835 
Gaspers J and Huotari M (2017) Turkey looks to China for security cooperation alternatives. The German Marshall Fund of the United States, Policy Brief No. 26. Available at https://www.gmfus.org/publications/turkey-looks-china-securitycooperation-alternatives (accessed 27 July 2021).

Gelpern A, Horn S, Parks B and Trebesch C (2021) How China lends: a rare look into 100 debt contracts with foreign governments. Center For Global Development. Available at https://www.cgdev.org/publication/how-china-lends-rare-look-into100-debt-contracts-foreign-governments (accessed 5 April 2021).

Gordon JN and Milhaupt CJ (2019) China as a national strategic buyer: toward a multilateral regime for cross-border M\&A. Columbia Business Law Review, 192.

Grell-Brisk M (2017) China and global economic stratification in an interdependent world. Palgrave Communications 3(1), 1-12.

Guo F, Huang C and Wu X (2019) Strategic analysis on the construction of new energy corridor China-Pakistan-Iran-Turkey. Energy Reports 5, 828-841.

Harutyunyan A (2020) China and Israel: evolving relationship within the Belt and Road Initiative. Asian Journal of Middle Eastern and Islamic Studies 14(3), 410-429.

Hillman JE (2020) The Emperor's New Road: China and the Project of the Century. New Haven and London: Yale University Press.

Huang Y (2016) Understanding China's Belt \& Road initiative: motivation, framework and assessment. China Economic Review 40, 314-321.

Hung H (2015) The China Boom: Why China will not Rule the World. New York: Columbia University Press.

Hung H (2018) The tapestry of Chinese capital in the Global South. Palgrave Communications 4(1), 1-6.

Hussain M and Jamali AB (2019) Geo-political dynamics of the China-Pakistan economic corridor: a new great game in South Asia. Chinese Political Science Review 4(3), 303-326.

Ikiz A (2019) Tek kuşak tek yol projesi ve Türkiye'ye olası etkileri. Electronic Journal of Social Sciences 18(72).

International Labour Organisation (ILO) (2021) Statistics on wages. Available at https://ilostat.ilo.org/topics/wages/ (accessed 27 July 2021).

Jacoby W (2014) Different cases, different faces: Chinese investment in Central and Eastern Europe. Asia Europe Journal 12(1-2), 199-214.

Jakimów M (2019) Desecuritisation as a soft power strategy: the Belt and Road Initiative, European fragmentation and China's normative influence in CentralEastern Europe. Asia Europe Journal 17(4), 369-385.

Jones L and Hameiri S (2020) Debunking the Myth of 'Debt-Trap Diplomacy'. London: Chatham House.

Jones L and Zeng J (2019) Understanding China's 'Belt and Road Initiative': beyond 'grand strategy' to a state transformation analysis. Third World Quarterly 40(8), $1415-1439$.

Karaca K (2019) Çin, Kuşak Yol ve Türkiye (No. 1; DARD Reports). Association for Research on Diplomacy.

Katsumata H and Nagata S (2019) ASEAN and the BRI: the utility of equidistant diplomacy with China and the US. Asian Journal of Peacebuilding 7.

Khalili L (2021) Growing pains [Review of The Emperor's New Road: China and the Project of the Century]. London Review of Books 43(6). 18 March 2021. Available at https://www.lrb.co.uk/the-paper/v43/n06/laleh-khalili/growing-pains 
Kim M (2019) A real driver of US-China trade conflict: the Sino-US competition for global hegemony and its implications for the future. International Trade, Politics and Development.

Kutlay $\mathbf{M}$ and Öniş Z (2021) Turkish foreign policy in a post-western order: strategic autonomy or new forms of dependence? International Affairs 97(4), 1085-1104.

Li X and Liu X (2005) Foreign direct investment and economic growth: an increasingly endogenous relationship. World Development 33(3), 393-407.

Liu H, Jiang J, Zhang $\mathbf{L}$ and Chen $\mathbf{X}$ (2018) OFDI agglomeration and Chinese firm location decisions under the 'Belt and Road' initiative. Sustainability 10(11), 4060.

Liu H, Wang Y, Jiang J and Wu P (2020) How green is the 'Belt and Road Initiative'? - Evidence from Chinese OFDI in the energy sector. Energy Policy 145, 111709.

Mazzucato M and Shipman A (2014) Accounting for productive investment and value creation. Industrial and Corporate Change 23(4), 1059-1085.

Metwally HAB (2018) BRI Chinese investment grabs Egypt's attention. China Focus. Available at http://www.cnfocus.com/bri-chinese-investment-grabs-egypts-attention/ (accessed 27 July 2021).

Nedopil C (2021) Countries of the Belt and Road Initiative (BRI) - green belt and road initiative center. IIGF Green BRI Center. Available at https://green-bri.org/ countries-of-the-belt-and-road-initiative-bri/ (accessed 5 April 2021).

Organisation for Economic Co-operation and Development (OECD) (2020) OECD International Direct Investment Statistics. Paris: OECD Publishing. https://doi. org/10.1787/g2g9fb42-en.

Oya C and Schaefer F (2019) Chinese Firms and Employment Dynamics in Africa: A Comparative Analysis. IDCEA Synthesis Report.

Özgentürk J (2021) Kanal İstanbul için dört Çinli şirket Ankara'da ihaleye hazırlaniyor. 9 April 2021. Available at https://www.cumhuriyet.com.tr/haber/ kanal-istanbul-icin-dort-cinli-sirket-ankarada-ihaleye-hazirlaniyor-1826770 (accessed 9 April 2021).

Parlar Dal E (2017) 'Belt and Road' project: China's new vision and Turkey. Istanbul: Anadolu News Agency. Available at https://www.aa.com.tr/en/analysis-news/ analysis-belt-and-road-project-chinas-new-vision-and-turkey/965994 (accessed 05 April 2021).

Parnell JA, Koseoglu MA, Long $Z$ and Spillan JE (2012) Competitive strategy, uncertainty, and performance: an exploratory assessment of China and Turkey. Journal of Transnational Management 17(2), 91-117.

Peled H and Harpaz MD (2018) Innovation as a catalyst in the China-Israel investment relationship: the China-Israel BIT (2009) and the Prospective FTA. In Society of International Economic Law (SIEL), Sixth Biennial Global Conference, July.

Quer D, Claver-Cortés E and Rienda L (2015) Chinese outward foreign direct investment: a review of empirical research. Frontiers of Business Research in China 9(3), 326-370. doi: 10.3868/s070-004-015-0014-6

Ramasamy B and Yeung M (2020) China's outward foreign direct investment (OFDI) to developing countries: the case of Central and Eastern Europe (CEE). Journal of the Asia Pacific Economy, 1-23.

Rana KS (2019) China's foreign ministry: fit for purpose in the era of Xi Jinping, BRI and 'Major Country Diplomacy with Chinese Characteristics'? China Report 55(3), 193-218.

Refinitiv (n.d.) BRI Connect Database. Available at https://www.refinitiv.com/en/ belt-road-initiative-data-insight (accessed 2 May 2021). 
Resmi Gazete (2021) Ithalatta hakslz rekabetin önlenmesine ilişskin teblĭ̆ (Tebliğ no: 2021/10). Available at https://www.resmigazete.gov.tr/eskiler/2021/04/2021040112.htm (accessed 27 July 2021).

Sanderson H and Forsythe M (2012) China's Superbank: Debt, Oil and Influence How China Development Bank is Rewriting the Rules of Finance. John Wiley \& Sons.

Shao X (2020) Chinese OFDI responses to the B\&R initiative: Evidence from a quasi-natural experiment. China Economic Review 61, 101435.

Singh A (2020) The myth of 'debt-trap diplomacy'and realities of Chinese development finance. Third World Quarterly 1-15.

Sneddon C (2015) Two. Building a 'world-wide fraternity': the bureau, China, and John Savage. In Concrete Revolution. Chicago: University of Chicago Press, pp. $28-51$.

Sparks C (2018) China's soft power from the BRICS to the BRI. Global Media and China 3(2), 92-99.

Szunomár Á and Peragovics T (2019) Hungary. An Assessment of ChineseHungarian Economic Relations. Prague Security Studies Institute (PSSI). Available at https://sha.static.vipsite.cn/media/thinktank/attachments/706891c 1a5153c5322cfcc10b5b9cc5f.pdf (accessed 27 July 2021).

Tao Z (2016) An alternative partner to the west? China's growing relations with Turkey. In Toward Well-Oiled Relations? London: Palgrave Macmillan, pp. 19-29.

Tekdal V (2019) Çin'in Kuşak ve Yol Girişimi ve Türkiye. In Yağcı M and Bakır C (eds), Çin Bilmecesi: Çin'in Ekonomik Yükselişi, Uluslararası Ilişskilerde Dönüşüm ve Türkiye. Istanbul: Koc Universitesi Yayinlari, pp. 125-142.

Trading Economics (2021) China GDP (1960-2019). Available at https:// tradingeconomics.com/china/gdp (accessed 12 March 2021).

Türkiye Cumhuriyet Merkez Bankası [Central Bank of the Republic of Turkey] (TCMB) (2020) EVDS Data Central: Foreign Direct Investments in Turkey. Ankara: TCMB. Available at https://evds2.tcmb.gov.tr/index.php?/evds/dashboard/ 4944 (accessed 21 April 2021).

Türkiye Cumhuriyeti Sanayi ve Teknoloji Bakanlığı [Republic of Turkey Ministry of Industry and Technology] (TCSTB) (2021) Uluslararası Doğrudan Yatırım (UDY) Istatistikleri. T.C. Sanayi ve Teknoloji Bakanlığı. Available at https://sanayi.gov. tr/istatistikler/yatirim-istatistikleri (accessed 5 April 2021).

Türkiye Cumhuriyeti Ticaret Bakanlığı [Republic of Turkey Ministry of Trade] (TCTB) (2021) T.C. Ticaret Bakanlığl, Bakanlık Istatistikleri. Ankara: TCTB. Available at https://ticaret.gov.tr/ (accessed 5 April 2021).

Türkiye Cumhuriyeti Ticaret Bakanlığı [Republic of Turkey Ministry of Trade] (TCTB) (2020) Çin Ülke Profili. T.C. Ticaret Bakanlı̆̆ D Dş̧ Temsilcilikler ve Uluslararası Etkinlikler Genel Müdürlügüu. Available at https://ticaret.gov.tr/ data/5f3b925713b876ea88e4c9c4/\%C3\%87\%C4\%B0N $\% 20 \% \mathrm{C} 3 \% \mathrm{BClke} \%$ 20profili.pdf (accessed 5 April 2021).

Türkiye İstatistik Kurumu [Turkish Statistical Institute] (TÜİK) (2021) İstatistik Veri Portall. Available at https://data.tuik.gov.tr/ (accessed 21 July 2021).

Türkiye Odalar ve Borsalar Birliği (TOBB) (2021) Kurulan ve Kapanan Şirket Istatistikleri. Available at https://www.tobb.org.tr/BilgiErisimMudurlugu/ Sayfalar/KurulanKapananSirketistatistikleri.php (accessed 5 April 2021).

Uluslararası Yatırımcılar Derneği [International Investors Association] (YASED) (2019) Uluslararast doğrudan yatırtmlar 2018 yll sonu değerlendirme raporu. Uluslararası Yatırımcılar Derneği. 
United Nations Conference on Trade and Development (UNCTAD) (2020) World Investment Report 2020: International Production Beyond the Pandemic. United Nations Publication. Sales No. E.20.II.D.23.

Völgyi K and Lukács E (2021) Chinese and Indian FDI in Hungary and the role of Eastern Opening policy. Asia Europe Journal 19(2), 167-187.

Vučić M (2020) European Union integration and the belt and road initiative: a curious case of Serbia. Medjunarodni problemi 72(2), 337-355.

Wang C (2018) Changing international system structures and the Belt and Road Initiative. In Rethinking the Silk Road. London: Springer, pp. 269-279.

World Bank (n.d.) World Development Indicators. Available at https://databank. worldbank.org/source/world-development-indicators (accessed 10 April 2021).

World Integrated Trade Solution (WITS) (2020) Data on Export, Import, Tariff, NTM. Available at https://wits.worldbank.org/ (accessed 5 April 2021).

Wong J and Chan S (2003) China's outward direct investment: Expanding worldwide. China: An International Journal 1(2), 273-301.

Wu J Zhang J Wu Y and Kong D (2020) When to go abroad: economic policy uncertainty and Chinese firms' overseas investment. Accounting \& Finance 60(2), 1435-1470.

Yean TS (2018) Chinese Investment in Malaysia: Five Years into the BRI. ISEAS Yusof Ishak Institute. Available at http://hdl.handle.net/11540/8046 (accessed 27 July 2021).

Yildiran M (2019) The Chinese vision of BRI and its effects on Turkey and West Asia. In China's Belt and Road Initiative in a Global Context. London: Springer, pp. 211-234.

Zheng D and van Vliet OP (2018) An empirical analysis of China's OFDI in ASEAN along 'the Belt and Road Initiative. Unpublished Master's Thesis, University of Leiden.

\section{About the Authors}

Burak Gürel is an assistant professor of sociology and co-director of the Center for Asian Studies at Koç University in Istanbul. Gürel earned his $\mathrm{PhD}$ from the Department of Sociology at The Johns Hopkins University in 2015. Gürel's publications have appeared in The Journal of Peasant Studies, Journal of Agrarian Change, Frontiers in Psychology, Review of Radical Political Economics, Rural China, and several edited volumes.

Mina Kozluca is a PhD student in the Department of International Development at the London School of Economics and Political Science. Kozluca holds an MSc in Development Studies from SOAS, University of London, and was a visiting researcher at Koç University Center for Asian Studies (KUASIA) in the 2020 2021 academic year. Her research focuses on the political economy of development, agrarian change, global commodity chains, and rural labour relations. 